\title{
Liver Cancer Pathologic Regional Lymph Nodes TNM Finding v7
}

National Cancer Institute

\section{Source}

National Cancer Institute. Liver Cancer Pathologic Regional Lymph Nodes TNM Finding v7. NCI Thesaurus. Code C90164.

A pathologic finding about one or more characteristics of liver cancer, following the rules of the TNM AJCC V7 classification system as they pertain to staging of regional lymph nodes. 